\title{
CRIMINAL JURISDICTION OF TRIBAL COURTS OVER NONMEMBER INDIANS: THE CIRCUIT SPLIT
}

\section{INTRODUCTION}

Since at least the 19th century the plight of the American Indian has occupied a place in the consciousness and conscience of many Americans. Students of American history know of the injustices that often have been done to Indians. As a result of increased concern in the past twenty years over Indian rights, the federal government has adopted policies designed to enhance tlie tribes' independence and self-governance. ${ }^{1}$

To exercise fully the powers of an independent government, a sovereign government inust be able to enforce its laws and resolve disputes through the exercise of judicial power. The extent to which Indian tribes have jurisdiction over disputes affecting their interests and the enforcement of their laws is an important measure of their sovereignty, as it is with state and federal governments.

An important and yet unresolved question directly related to the sovereignty of Indian tribes is whetler the tribes liave criminal jurisdiction over Indians who are not inembers of the tribe, but who commit crimes on the tribes' reservations. To answer this jurisdictional question requires an understanding of many significant factors and principles controlling Indian tribe jurisdiction, mcluding the special status the tribes have under federal and state law.

The Indian tribes have a unique relationship witl the Umited States government. ${ }^{2}$ Once a people who possessed full sovereignty over their lands, ${ }^{3}$ the Enropean conquest drastically altered the Indians' status to

1. See infra notes 183-89 and accompanying text.

2. Cherokee Nation v. Georgia, 30 U.S. (5 Pet.) 1, 16 (1831). Justice Marshall speaking for the Court stated that "[ $[t]$ he condition of the Indians in relation to the United States is perhaps unlike that of any other two people in existence... . [T] he relation of the Indians to the United States is marked by pecuhar and cardimal distinctions which exist nowhere else."

3. Having complete sovereignty over their territories implies that the tribes possessed "all the powers of any sovereign state." F. COHEN, HaNDBOOK OF FEDERAL INDIAN LAW 123 (1942) (quoting statement by the Department of the Interior explaining retained sovereign powers of the Indian tribes). 
one of semi-independence. ${ }^{4}$ As a result of this transformation, Indian tribes became dependent on the United States "to restrain the disorderly and licentious froin intrusions into their country ...."s Despite the fact that Indian tribes are under extensive federal control, tliey have remained "a separate people, with tlie power of regulating their internal and social relations ...." According to federal law, the tribes retain all aspects of sovereignty that liave not been terminated by Congress and are not "inconsistent witl their status" as a dependent nation. ${ }^{7}$ Thus, a tribe has the power to determine tribal nembership, ${ }^{8}$ to regulate domestic relations among its inembers, ${ }^{9}$ and to prescribe rules for the inheritance of property. ${ }^{10}$ In addition, an Indian tribe undisputably lias the authority to enforce its criminal laws agamst its own inembers. 11

Determing who is a inember of a tribe, and dealing with inembers and nonmembers of tribes, has becoine more complicated as of late. Through intermarriage and government programs that increase contact between tribes, Indians often reside on reservations or have siguificant contacts witl tribes to which they do not belong.12 As a result of their

4. Cherokee Nation, 30 U.S. (5 Pet.) at 16.

5. Worchester v. Georgia, 31 U.S. (6 Pet.) 515 , 552 (1832).

6. United States v. Kagama, 118 U.S. 375, 381-82 (1880); see also Cherokee Nation, 30 U.S. (5 Pet.) at 16 (Cherokees recognized by the United States "as a distinct political society, separated from others, capable of managing [their] own affairs and governing [themselves]. ..."); Act of Aug. 7, 1789, ch. 8, art. 3, 1 Stat. 50, 52 ("The utmost good faith shall always be observed toward the Indians; their land and property shall never be taken from them without their consent; and in their property, rights, and liberty, they never shall be invaded or disturbed ...."). follows:

The Department of the Interior has described the retained powers of the Indian tribes as

(1) An Indian tribe possesses, in the first instance, all the powers of any sovereign state. (2) Conquest renders the tribe subject to the legislative power of the United States and, in substance, terminates the external powers of sovereignty of the tribe, . . . but does not by itself affect the internal sovereignty of the tribe .... (3) These [internal] powers are subject to qualification by treaties and by express legislation of Congress, but, save as thus expressly qualified, full powers of internal sovereignty are vested in the Indian tribes and in their duly constituted organs of government.

Quoted in F. COHEN, supra note 3, at 123.

7. See Oliphant v. Suquamish Indian Tribe, 435 U.S. 191, 208 (1978); United States v. Wheeler, 435 U.S. 313, 323 (1978).

8. See, e.g., Cherokee Intermarriage Cases, 203 U.S. 76, 95 (1906); Roff v. Burney, 168 U.S. 218, 222 (1897).

9. See, e.g., Fisher v. District Court, 424 U.S. 382, 389 (1976) (adoption of Indian child by Indians within jurisdiction of tribal court to the exclusion of state courts); United States v. Quiver, 241 U.S. 602, 604 (1915).

10. See Jones v. Meehan, 175 U.S. 1, 29 (1899); United States ex rel. Mackey v. Coxe, 59 U.S. (18 How.) 100, 102 (1855).

11. United States v. Wheeler, 435 U.S. 313, 322 (1978).

12. See infra notes $29-33$ and aecompanying text. 
contacts with the reservations, these nonmember Indians ${ }^{13}$ have an impact upon the sovereignty and interests of the tribal government. This impact manifests itself in the resolution of the complicated and important question whether a tribal court possesses criminal jurisdiction over nonmember Indians who have significant ties to a reservation.

Criminal jurisdiction rules for crimes committed on Indian reservations form a confusing inaze of federal, state, and tribal court authority. Which court can assert jurisdiction depends upon what type of crime was allegedly committed, and whether non-Indians and Indians were involved. ${ }^{14}$ Unfortunately, the relevant treaties, federal statutes, and Supreme Court decisions do not explicitly define where nonmember Indians fit into this jurisdictional scheme. If they are treated as non-Indians, the proper forum will be either a state or federal court. ${ }^{15}$ Only if these nonmember Indians are considered tribal meinbers nnay a tribal court maintam criminal jurisdiction over them. ${ }^{16}$

Two circuits have addressed the question of criminal jurisdiction over nonmember Indians who allegedly committed crimes on the reservation. In Duro v. Reina, ${ }^{17}$ the Umited States Court of Appeals for the Ninth Circuit held that Indian tribal courts have jurisdiction over nonmember Indians who have significant contacts to the reservation and

13. A "nonmeuber Indian" is an individual of Indian blood who is not officially enrolled in the tribe at issue. See, e.g., Washington v. Confederated Tribes, 447 U.S. 134, 160 (1980) ("nonmembers" include those Indians "resident on the reservation but not enrolled in the governing Tribe"); Duro v. Reina, 851 F.2d 1136, 1138 (9th Cir. 1988) (enrolled inember of Torrez-Martinez band of Mission Indians is a nonmeinber of the Salt River Indian Reservation); Greywater v. Joshua, 846 F.2d 486, 487 (8th Cir. 1988) (enrolled members of the Turtle Mountain Band of Chippewa Indians are nonmeinbers of the Devils Lake Sioux Tribe).

14. See infra notes 57-82 and accoinpanying text.

15. See infra note 27,70 and accoinpanying text.

16. See infra note 66 and accompanying text. Also, a tribal court has civil jurisdiction over non-Indians in certain instances. See Iowa Mut. Ins. Co. v. LaPlante, 480 U.S. 9 (1987) (Blackfeet Tribal Court had jurisdiction over conduct of non-Indian in personal injury claim); Williams v. Lee, 358 U.S. 217, 223 (1959) (Naveja Tribal Court had jurisdiction over non-Indian in civil collections suit).

17. 851 F.2d 1136 (9th Cir. 1988). The United States Supreme Court has granted review on Duro. 109A S. Ct. 1930 (1989). The questions presented on review are stated as follows:

(1) In light of fact that Indian tribes cannot exercise criminal jurisdiction over non-Indians, does Salt River Pima-Maricopa tribe have criminal jurisdiction over petitioner, who is not nember of the tribe? (2) Are equal protection guarantees of Indian Civil Rights Act, 25 U.S.C. 1302, violated if Indian tribes are precluded froun exercising criminal jurisdiction over non-1nember, non-Indians, but inay exert jurisdiction over similarly situated nonmeinber Indians based solely on race? (3) May petitioner, who is Cahuilla Indian, be subjected to criminal jurisdiction of Salt River Pima-Maricopa tribe because his girlfriend was tribal nember and he temporarily resided on Salt River reservation? (4) Can criminal jurisdiction over non-member Indians be predicated, on case-by-case basis, because of significant "contacts" between accused and Indian tribe?

57 U.S.L.W. 3744 (U.S. May 9, 1989). 
are accused of coinmitting crimes there. In Greywater v. Joshua, ${ }^{18}$ the United States Court of Appeals for the Eighth Circuit reached the opposite result, holding that the exercise of jurisdiction conflicts with an Indian tribe's status as a dependent nation.

Despite the inconsistency in these holdings, both courts based their analysis on the Suprenie Court's decision in Oliphant v. Suquamish Indian Tribe. ${ }^{19}$ In Oliphant, the Court held that tribal courts do not have criminal jurisdiction over non-Indians. ${ }^{20}$ In holding so, the Court established a three-part test for determining whether a tribe has been deprived of sonie aspect of its sovereignty and, lience, its jurisdiction. Indian tribes, according to the Court, may not exercise powers of a sovereign state that have been withdrawn by either (1) treaty, or (2) statute, or (3) that conflict witli tlie tribes' status as dependent nations. ${ }^{21}$ The dependent status prong of the Oliphant test focuses on whether the exercise of some aspect of tribal power conflicts with an overriding federal interest. ${ }^{22}$

This Note analyzes criminal jurisdiction over nonnieniber Indians and the conflicting opmions of the Eiglitl and Ninth Circuits in light of the three part test set forth in Oliphant. First, in order to give context to the current disputes, the Note examines the realities of tribal composition and tribal niembership rules. ${ }^{23}$ Second, the Note argues that the treaties between the federal government and the tribes do not divest the tribes of criminal jurisdiction over nonniember Indians. ${ }^{24}$ Third, the discussion points out that current laws neither expressly assign criminal jurisdiction over nonmenibers to the federal or state courts, nor preclude the jurisdiction of the tribal courts; thus, the laws leave open the possibility of tribal court jurisdiction over nonmember Indians. ${ }^{25}$ Finally, the Note concludes, contrary to tlie Eiglit Circuit's holding in Greywater, that the exercise of criminal jurisdiction over nonmenibers does not stand out as mconsistent witl a tribe's dependent status as described in Supreme Court decisions and current federal policy, nor with the practical realities of tribal niembership and self-governance. ${ }^{26}$

\footnotetext{
18. 846 F.2d 486 (8th Cir. 1988).

19. 435 U.S. 191 (1978).

20. Id. at 212 .

21. Id. at 208.

22. Id. at 209.

23. See infra notes 27-56 and accompanying text.

24. See infra notes $\mathbf{1 2 0 - 3 6}$ and accompanying text.

25. See infra notes $\mathbf{1 3 7 - 4 6}$ and accompanying text.

26. See infra notes 147-214 and accompanying text.
} 


\section{Tribal Composition AND Membership RUles}

Historically, the focus of U.S. law has been on the Indian tribes rather than on Indians as individuals. ${ }^{27}$ This emphasis on tribal entities, which continues today, furthers current federal policy aimed at strengthening tribal governments and promoting the separate cultural, political, and economic development of Indians. ${ }^{28}$

However, the orgamization of the Indians into various tribes sometimes came as a result of external force, rather than natural familial and cultural groupings. Prior to the Europeans' arrival in America, changes in tribal composition occurred when members of one tribe captured members of another in war, or when members of different tribes internuarried. ${ }^{29}$ After the establishment of the United States government, scattered Indian communities with no formal pohtical organization were often forced into tribal groupings and a "chief" was appointed by a federal agent or by Indians themselves, to facilitate treaty-inaking with the United States. ${ }^{30}$ Similarly, Congress often has created "consolidated" or "confederated" tribes, sometimes coinposed of Indians that do not even speak the saine language, to form a single pohtical entity with which the government can carry on relations. ${ }^{31}$ Once established, these "tribes" largely have continued to exist as units. ${ }^{32}$

Over time, the tribes solidified internal control by establishing ineinbership rules similar to those existing in natural tribal groups. Although

27. The European colonists who arrived in North America naturally negotiated with tribes rather than individuals because the tribes treated land as a collective resource and possessed considerable military power. See Clinton, Isolated in Their Own Country: A Defense of Federal Protection of Indian Autonomy and Self-Government, 33 STAN. L. REv. 979, 986 (1981). The U.S. government continued the practice by dealing with the Indians collectively in both treaties and statutes. Id. at 987.

28. Id. at $988-89$.

29. Miller v. Crow Creek Sioux Tribe, 12 Ind. L. Rptr. 6008, 6009 (Intertr. Ct. App. 1984).

30. Clinton, supra note 27, at 987-88. See, e.g., Washington v. Fishing Vessel Ass'n, 443 U.S. $658,664 \mathrm{n} .5$ (1979) (territorial officials aggregated loose bands into tribes and appointed chiefs when treaties securing fishing rights were signed); Oliphant v. Suquamish Indian Tribe, 435 U.S. 191, 192 (1978) (related Indian villages bordering Puget Sound were aggregated into a series of tribes prior to the 1855 treaty); United States v. Washington, 520 F.2d 676, 682 (9th Cir. 1975) (as part of treaty negotiations, scattered Indian communities were united imto a number of tribes with appointed chiefs).

31. Clinton, supra note 27, at 987-88. Such composite tribes include the Wind River Tribes (the Shoshone and Arapahoe Indians), the Cheyenne-Arapahoe Tribes of Oklahoma, the Cherokee Nation of Oklahoma (including the Cherokees, Delawares, Shawnees, and others), and the Confederated Salish and Kootenai Tribes of the Flathead Reservation.

32. See, e.g., Washington, 520 F.2d at 692 (Muckleshoot Indian tribe, a product of arbitrary consolidation in 1855 , continues as a discrete tribe today). 
tribal constitutions include among their recognized members those Indians whose names appear on an official census roll, ${ }^{33}$ the qualifications for membership vary considerably from tribe to tribe. For example, soine constitutions provide that every child born to any meinber of the tribe or community autonatically becomes a tribe member, ${ }^{34}$ whereas others provide that interested Indians must apply for menbership, ${ }^{35}$ or that a child may not become a member until he reaches the age of inajority. ${ }^{36}$ Some tribes have patrilineal membership rules, altogether excluding from membership children from intertribal marriages who live on the mother's reservation. ${ }^{37}$ Further, some constitutions permit new membership for Indians who simply become residents of the reservation ${ }^{38}$ or desire affiliation with the reservation, ${ }^{39}$ whereas others have no such provision. ${ }^{40} \mathrm{Fi}$ nally, other constitutions recognize a loss of membership when a meinber Indian moves away from the reservation ${ }^{41}$ or is found guilty of misconduct on the reservation, ${ }^{42}$ whereas others have no provision for deprivation of membership status. ${ }^{43}$

Thus, as a practical matter, the wide array of tribal membership requirements make it possible for an Indian to reside indefinitely on the reservation of a tribe without ever becoming a member, even if inembership in another tribe has terminated. For example, an Indian of the Wrangell Cooperative Association in Alaska who inoves away from the reservation and establishes residence with the Prairie Island Indian Commumty in Minnesota will lose his membership with the Wrangells, ${ }^{44}$ but

33. See, e.g., CONST. of THE Shakopee Mdewakanton Sioux CoMmunity of MinN. art. II, $\S 1$ 1(a); Const. AND ByLAws OF THE PRAIRIE IsLAND INDIAN COMMUNITY IN MINN. art. III, $\S 1$ (a); Const. AND BYLAwS OF THE AKIACHaK NATIVE Community art. II, $\S 1$.

34. See, e.g., Const. and Bylaws of the Saginaw Chippewa Indian TRIbe of Mich., art. III, $\S 1(b)$.

35. See, e.g., REVISEd CoNSt. AND Bylaws OF THE MINN. ChIPPEWA TRIBE art. II, $\S 1$ 1(b).

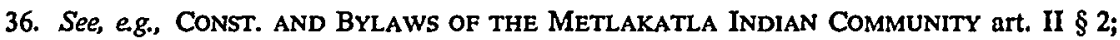
Const. AND Byl.Aws OF tHe Petersburg INdian Ass'N, art. II, § 3.

37. Santa Clara Pueblo v. Martinez, 436 U.S. 49, 49 (1978).

38. See, e.g., Const. and Bylaws of the Petersburg Indian Ass'N art. II, § 1(b); Const. AND BYLAWS OF THE AKIACHAK NATIVE COMMUNITY art. II, $\S 4$.

39. See, e.g., Const. AND Bylaws of THE KeWEenaw Bay Indian Community art. II, $\S 2$.

40. See, e.g., Const. and Bylaws of the Prairie Island Indian Community in MinN. art. III.

41. See, e.g., Const. and Bylaws of the Akiachak Native Community art. II, §3; CONST. AND BYLAWS OF THE Native VillaGe OF DeERING art. II, § 3; CoNST. AND BYLAWS OF THE AKIAK NATIVE COMMUNITY art. II, § 3.

42. See, eg., Const. and Bylaws of the Organized Village of Kake art. II, \& 3; CONST. AND Bylaws OF the Hydaburg COOPERATIVe Ass'N art. II, § 2(c).

43. See Const. of the Shakopee Mdewakanton Sloux Community of Minn. art. II.

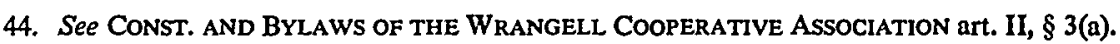


still not qualify for enrollment with the Prairie Island Community.45 Similarly, a full-blooded Indian having parents of different tribal backgrounds n1ay be ineligible for tribal n1embership on the reservation where he resides. ${ }^{46}$ While nonmember status prevents an Indian from votnig or holding tribal office, ${ }^{47}$ nonmembers who reside on the reservation or regularly participate im reservation life are generally accepted by other residents as an integral part of the tribal community. ${ }^{48}$

In recent years, federal governmental policies regarding the Indians have encouraged movement of Indians among tribes. During the heiglit of the assimilation period, the Vocational Training Program ${ }^{49}$ renioved large groups of Indians from reservations and placed them in urban areas which becaine "nielting pots" for Indians of different tribal ancestry. ${ }^{50}$ The establishment of the Bureau of Indian Affairs (B.I.A.), ${ }^{51}$ which set up an eniploynient preference for Indians in Indian programs, resulted in the presence of niany nonmeniber Indians on reservations. Likewise, the Indian Child Welfare Act, ${ }^{52}$ which gave tribes the authority to transfer court proceedings involving minors back to tribal courts and established an order of preference for adoptive ${ }^{53}$ and pre-adoptive ${ }^{54}$ placement of Indian children, also led to the placenient of children from one tribe on to the reservation of another. 55

Such practices and policies have resulted in continually clianging tribal conipositions. Thus, today there are two situations of note: tribes

45. See Const. AND ByLAws of the Prairie IsLANd INDIAN Community in MinN. (June 20, 1976).

46. See, e.g., Santa Clara Pueblo v. Martinez, 436 U.S. 49, 72 (1978) (full-blooded Indian children of Santa Clara Pueblo inother and Navajo father ineligible for tribal inembership since Santa Clara Pueblo ineunbership rule was patrilineal).

47. Greywater v. Joshua, 846 F.2d 486, 493 (1988).

48. Clinton, supra note 27 , at 1015-16.

49. 25 U.S.C. $\S 309$ (1982).

50. Miller v. Crow Creek Sioux Tribe, 12 Ind. L. Rptr. 6008, 6009 (Intertr. Ct. App. 1984).

51. Act of July 9, 1832, ch. 174, § 1, 4 Stat. $564,564$.

52. 25 U.S.C. $\S 1901$ (1982).

53. 25 U.S.C. $\S 1915$ (a) (1982) provides the following:

In any adoptive placeinent of an Indian child under State law, a preference shall be given, in the absence of good cause to the contrary, to a placelnent with (1) a nember of the child's extended family; (2) other inembers of the Indian child's tribe; or (3) other Indian families.

54. 25 U.S.C. § 1915(b) provides the following:

In any foster care or preadoptive placeinent, a preference shall be given, in the absence of good cause to the contrary, to a placennent with-

(i) a nember of the child's extended family;

(ii) a foster home licensed, approved, or specified by the Indian child's tribe;

(iii) an Indian foster home licensed or approved by an authorized non-Indian licensing authority; or

(iv) an institution for children approved by an Indian tribe or operated by an Indian organization which has a program suitable to ineet the Indian child's needs.

55. Miller v. Crow Creek Sioux Tribe, 12 Ind. L. Rptr. 6008, 6010 (Intertr. Ct. App. 1984). 
currently encompass Indians of not necessarily the same background, and many nonmembers inehgible for tribal enrollment presently reside on reservations. ${ }^{56}$

\section{The Current Statutory Scheme for Criminal JURISDICTION IN INDIAN COUNTRY}

As a result of the dependent status of the Indian tribes, the federal government has plenary authority to enact legislation that deprives the tribes of important aspects of their imherent sovereignty. 57 Congress has freely exercised its powers to alter the jurisdiction of tribal courts. ${ }^{58}$ The most recent changes reflect the federal government's increased concern with crimes committed by and against Indians in Indian country and the need to ensure that the courts and laws dealing with these crimes prove adequate. Presently, crimmal jurisdiction within "Indian country"59 is divided among federal, state, and tribal courts. ${ }^{60}$ Although many statutes touch on the issue of criminal jurisdiction in Indian country, the three most important statutes for the purposes of this Note are the General Crimes Act, ${ }^{61}$ the Major Crimes Act, ${ }^{62}$ and Public Law 280.63

The General Crimes Act, passed in its original form in $1817,{ }^{64}$ provides the federal government with broad jurisdiction over all crimes involving an Indian and a non-Indian that occur in Indian country. The

56. Id.

57. Santa Clara Pueblo v. Martinez, 436 U.S. 49, 60 (1978); Talton v. Mayes, 163 U.S. 376, 384 (1896); United States v. Kagama, 118 U.S. 375, 380 (1886); Ex parte Crow Dog, 109 U.S. 556, 559 (1883).

58. See, e.g., General Crimes Act, 18 U.S.C. \$ 1152 (1988) (discussed infra notes $64-66$ and accompanyimg text); Major Crimes Act, 18 U.S.C. \$ 1153 (1988) (discussed infra notes 68-72 and accompanying text); Act of Aug. 15, 1953, Pub. L. No. $83-280 \S \S 1-4,6,7,67$ Stat. 588 (codified as amended at 18 U.S.C. $\S 1162$ (1982), 28 U.S.C. $\$ 1360$ (1982 \& Supp. V 1987), and 25 U.S.C. $\S \S 1321-1326$ (1982)) (discussed infra notes 73-82 and accoinpanying text).

59. "Indian country" is defined in 18 U.S.C. $\S 1151$ (1988):

"Indian country" ... neans (a) all land within the linits of any Indian reservation under the jurisdiction of the United States Government, notwithstanding the issuance of any patent, and, including rights-of-way runnimg through the reservation, (b) all dependent Indian communities within the borders of the United States whether within the original or subsequently acquired territories thereof, and whether within or without the limits of a state, and (c) all Indian allotments, the Indian titles to which have not been extinquished, including rights-of-way running through the same.

60. See generally Clinton, Criminal Jurisdiction Over Indian Lands: A Journey Through a Jurisdictional Maze, 18 AR1Z. L. REV. 503 (1976) (explaining when the federal government, the states, and the Indian tribes have jurisdiction).

61. 18 U.S.C. $\$ 1152$ (1988).

62. 18 U.S.C. $\S 1153(1988)$.

63. Act of Aug. 15, 1953, Pub. L. No. 83-280, $\S 1-4,6,7,67$ Stat. 588 (codified as amended at 18 U.S.C. $\S 1162$ (1988), 28 U.S.C. $\S 1360$ (1982), and 25 U.S.C. $\$ \S 1321-1326(1982)$ ).

64. Act of March 3, 1817, ch. 92, § 1, 3 Stat. 383, 383 ("any Indian, or other person or persons ... within any town, district, or territory, belonging to any nation or nations, tribe or tribes, of 
1817 Act incorporated prior federal statutes and treaties that had divested tribes of exclusive jurisdiction over crimes committed in Indian territories. ${ }^{65}$ In its current form, the Act explicitly excepts froin federal jurisdiction any crime committed by one Indian against another, any Indian already punished by a tribal court, and any crime for which tribal jurisdiction is explicitly authorized by treaty. ${ }^{66}$ Although no exception is built into the language of the Act for crimes between non-Indians which occur on a reservation, the Suprenie Court has lield that such crimes fall under state, ratlier than federal, jurisdiction. ${ }^{67}$

The Major Crimes Act further extends federal jurisdiction over crimes committed in Indian country. The Act's predecessor was enacted by Congress in response to the Suprenie Court's 1883 holding in Ex parte Crow Dog. 68 In Crow Dog, the Court ordered the defendant's release from prison because it found, based on the existing federal statutes and the Treaty of 1868 witl the Sioux, that the district court did not have jurisdiction over an Indian who liad inurdered another Indian within Indian country. ${ }^{69}$

Currently, the Act confers federal jurisdiction over fourteen major crimes involving Indian perpetrators. ${ }^{70}$ Althougl the primary purpose

Indians" are under federal criminal jurisdiction, except crimes "committed by one Indian against another, within any Indian boundary").

65. See generally Clinton, supra note 60 , at $522 \mathrm{n} .89$ (listing prior statutes and the treaties which they replaced). The effect of the General Crimes Act is to extend federal enclave law to Indian country where a crime involves both Indians and non-Indians. A federal enclave is a federally created and administered area "within the exclusive jurisdiction of the United States," 18 U.S.C. § 1153 (1988), such as a national park, which draws its criminal law from both state defined and federallydefined crimes as dictated by the Assimilative Crimes Act, 18 U.S.C. $§ 13$ (1988).

66. 18 U.S.C. $\S 1152$ (1988). The exact wording of the General Crimes Act reads as follows: Except as otherwise provided by law, the general laws of the United States as to the punishment of offenses coinmitted in any place within the sole and exclusive jurisdiction of the United States, except the District of Columbia, shall extend to Indian country.

This section shall not extend to offenses committed by one Indian against the person or property of another Indian, nor to any Indian comnitting any offense in the Indian country who has been punished by the local law of the tribe, or to any case where by treaty stipulations, the exclusive jurisdiction over such offenses is or may be secured to the Indian tribes respectively.

Because an Indian already tried and punished in a tribal court is not subject to federal jurisdiction, federal jurisdiction over Indians is not exclusive, but concurrent with tribal jurisdiction.

67. New York ex rel. Martin, 326 U.S. 496, 497 (1946); Draper v. United States, 164 U.S. 240, 247 (1896); United States v. McBratney, 104 U.S. 621, 624 (1881). The Court depends on the insignificance of any Indian interest in crimes betwecn non-Indians on Indian land. The rationale behind the Court's awarding jurisdiction over crimes between non-Indians to states is that no Indian interest is involved in crimes of this sort. Therefore, the Court sees no need to invoke federal jurisdiction to fulfill the guardianship responsibility of the federal government.

68. 109 U.S. 556 (1883).

69. Id. at $567-68$.

70. 18 U.S.C. $\$ 1153$ (1988). The exact wording of the Major Crimes Act reads as follows:

(a) Any Indian who commits against the person or property of another Indian or other person any of the following offenses, namely, murder, manslaughter, kidnaping, maining, 
of the Act is to punish an Indian who commits a major crime against another Indian as if the crime had been committed in a federal enclave, ${ }^{71}$ the Act applies whether the victim is an Indian or not. It is not clear whether jurisdiction under the Major Crimes Act rests exclusively in the federal courts or whether tribal courts retain concurrent jurisdiction. ${ }^{72}$

Public Law 280 is the third major federal statute controlling criminal jurisdiction in Indian country. Public Law 280 was passed in 1953 during the height of the "termination era," 73 when Congress focused on making "the Indians within ... the United States subject to the same

a felony under chapter 109A, incest, assault with intent to commit murder, assault with a
dangerous weapon, assault resulting in serious bodily injury, arson, burglary, robbery, and
a felony under section 661 of this title within the Indian country, shall be subject to the
same laws and penalties as all other persons committing any of the above offenses, within
the exclusive jurisdiction of the United States. (b) Any offense referred to in subsection (a)
of this section that is not defined and punished by federal law in force within the exclusive
jurisdiction of the United States shall be defined and punished in accordance with the laws
of the State in which such offense was committed as are in force at the time of such offense.

The original predecessor to the Major Crimes Act, Act of Mar. 3, 1885, ch. 341, §9, 23 Stat. 362,

385, conferred federal jurisdiction over only seven major crimes: murder, manslaughter, rape, assault with intent to kill, arson, burglary, and larceny.

71. See supra note 65.

72. Unlike the General Crimes Act, the Major Crimes Act does not expressly exclude federal court jurisdiction where the crime has already been tried by a tribal court. For a case supporting concurrent jurisdiction, see Talton v. Mayes, 163 U.S. 376 (1896) (Supreme Court let murder conviction by court of the Cherokee Nation stand even though the defendant was convicted in 1892, seven years after the Major Crimes Act was passed). See also Clinton, supra note 60, at 559 n.295 (pointing out that the legislative history of the Major Crines Act supports concurrent jurisdiction). But see Sam v. United States, 385 F.2d 213, 214 (10th Cir. 1967) (prosecution of Indian for rape of another Indian within Indian country is case not within tribal court jurisdiction); Glover v. United States, 219 F. Supp. 19, 20 (D. Mont. 1963) (jurisdiction of criminal offenses by Indians in the Indian country rests with Indian tribes, except where withdrawn by Congress); Iron Crow v. Ogallala Sioux Tribe, 129 F. Supp. 15, 18 (W.D.S.D. 1955) (since Congress authorized the creation of tribal courts, the tribal court had jurisdiction to try aceused for adultery). It is clear, however, that the federal jurisdiction conveyed by the Major Crimes Act excludes state jurisdiction. United States v. Kagama, 118 U.S. 375, 383-84 (1886) (Act of March 31, 1885 inplicitly excludes states froin exercising jurisdiction over Indians for matters covered by the Act).

A suppleinent to the Major Crimes Act was enacted in 1948. 18 U.S.C. § 3242 (1988). Section 3242 provides that an Indian "shall be tried in the same courts and in the same manner as are all other persons committing such offense." In other words, an Indian tried in federal court is subject to the same procedures as a non-Indian. See Keeble v. United States, 412 U.S. 205, 208 (1973) ("defendant is entitled to an instruction on a lesser included offense if the evidence would permit a jury rationally to find him guilty of the lesser offeuse and acquit hin on the greater"). To the extent the Major Crimes Act governs offenses committed by an Indian against the person or property of a nonIndian, it overlaps with the General Crimes Act. Although the Supreme Court has never ruled on the question of which statute takes precedence when both may apply, lower courts faced with this situation have held that the Major Crimes Act controls. United States v. John, 587 F.2d 683, 685 (5th Cir. 1979); Henry v. United States, 432 F.2d 114, 118 (9th Cir. 1970).

73. The "termination era" extended froin the 1940 to the early part of the 1960. During this period, federal trust responsibilities were terminated for approximately 109 Indian tribes and bands, and in some cases, tribes were disbanded altogether. In addition, Bureau of Indian Affairs programs encouraged urbanization of Indians. See generally M. PRICE \& R. CLINTON, LAW AND THE AMERICAN INDIAN 83-86 (1983) (summary of termination period policies and programs). 
laws and entitled to the same privileges and responsibilities as are applicable to other citizens of the Umited States."74 The law mandated six states $^{75}$ to assume exclusive criminal jurisdiction over crimes committed "by or agamst Indians" on Indian reservations within their territories. ${ }^{76}$ In addition, Public Law 280 provided that any other state could"discretionarily assume Public Law 280 jurisdiction by legislative action. ${ }^{77}$ Six additional states have taken that step. ${ }^{78}$

Fifteen years after enactment, Public Law 280 was significantly amended by the Indian Civil Riglits Act of $1968 .{ }^{79}$ In accordance with the new "self-determination" policy, which the federal government began to pursue in early $1960,{ }^{80}$ the revised Public Law 280 required tribal consent prior to any state's assumption of jurisdiction. ${ }^{81}$ Significantly, no tribe has consented to state jurisdiction since the statute's enactment im 1968. In addition to the twelve states that assumed jurisdiction under Pubhic Law 280 prior to 1968, about eiglit states still exercise some degree of criminal jurisdiction over Indians in Indian country pursuant to other federal legislation. 82

In summary, the federal government has exclusive jurisdiction over crimes committed in Indian country by non-Indians against Indians, and concurrent jurisdiction over crimes perpetrated by Indians if the victim was a non-Indian and the defendant has not been tried already by a tribal

74. H.R. Con. Res. 108, 67 Stat. B132 (1953).

75. When originally enacted, Public Law 280 conferred jurisdiction on five states: California, Minnesota, Nebraska, Oregon, and Wisconsm. When Alaska was admitted as a state, it was added to tlie list. Act of Aug. 8, 1958, Pub. L. No. 85-615, $\S 1,72$ Stat. 545, 545.

76. Act of Aug. 15, 1953, Pub. L. No. $83-280, \S \S 1-4,67$ Stat. 588, 588-90 (codified as amended at 18 U.S.C. $\S 1162$ (1982), 28 U.S.C. $\S 1360$ (1982 \& Supp. V 1987), 25 U.S.C. $\$ \S 1321-1326$ (1982)). California and Nebraska were granted criminal jurisdiction over all reservations within their boundaries. The Red Lake Reservation was excluded from Minnesota's mandatory jurisdiction, the Warm Springs Reservation was excluded from Oregon's mandatory jurisdiction, and the Menominee Reservation was excluded from Wisconsm's mandatory jurisdiction.

77. Id. $\S \S 6,7$.

78. Florida, Idaho, Montana, Nevada, Utah, and Washington all assumed criminal jurisdiction over all or part of Indian reservations witlin their states under the discretionary provision of Public Law 280. See Fla. STat. ANN. $\S 285.16$ (West 1975); Idaho Code $\S \S 67-5101$ to -5103 (1989); MONT. CODE ANN. $\$ \S 83-801$ to -806 (1966); NEv. REV. STAT. $\S 41.430$ (1986); UTAH CODE ANN. $\S \S 63-36-9$ to -21 (1989); WASH. REV. CODE ANN. $\S \S 37.12 .010$ to -.070 (1964).

79. Pub. L. No. 90-284, $\S$ 201-03, $\S 301-02, \S \S 401-06,82$ Stat. 73 (codified as amended at 25 U.S.C. $\S \S 1301-03,1311-12,1321-26$ (1982 \& Supp. V 1987)).

80. See infra notes $183-89$ and accompanying text. The policy of self-determination remains the current federal viewpoint.

81. 25 U.S.C. $\$ \S 1321-22$ (1982). The requirement for tribal consent was not made retroactive. States may, if they cloose, retrocede the jurisdiction they obtained under Public Law 280. 25 U.S.C. $\S 1323$ (1982).

82. The eiglit states are Arizona, Iowa, Kansas, New Mexico, New York, North Carolina, Nortl Dakota, and Oklahoma. For a full explanation of the source and extent of the various states' jurisdiction, see Clinton, supra note 60 , at 577-83. 
court. The federal government also has jurisdiction if the crime allegedly committed by one Indian against another fits one of the fourteen crimes specified in the Major Crimes Act. State courts have exclusive jurisdiction over crimes committed by a non-Indian against another non-Indian in Indiân country, and jurisdiction over crimes coinmitted by or against Indians on reservations within their boundaries, provided that jurisdiction has been conferred pursuant to Public Law 280 or other statutes. Tribal courts in states other than those presently governed by Public Law 280 or similar statutes have exclusive jurisdiction over all crimes committed by an Indian except those in the Major Crimes Act, and inay have concurrent jurisdiction over those crimes as well.

The current jurisdictional scheme does not specify clearly which court has jurisdiction over nonmeinber Indians in the case of non-major crimes. However, as the Duro court pointed out and as will be explained further in section IV, the statutory scheme supports the arguinent that a tribal court has jurisdiction in these cases.

\section{The CiRCUIT SPLiT}

The leadimg Supreme Court case in this area, Oliphant v. Suquamish Indian Tribe, involved a non-Indian who had been arrested by tribal authorities for assaulting a tribal officer and resisting arrest. ${ }^{83}$ Oliphant claimed that the Suquamish Indian Provisional Court did not have criminal jurisdiction over non-Indians, and he petitioned the district court for a writ of habeas corpus. The district court demied the petition, and the Court of Appeals for the Ninth Circuit affirmed. The Supreme Court granted certiorari to determine whether Indian tribal courts have criminal jurisdiction over non-Indians. The Court ruled that they do not. ${ }^{84}$

In reaching this conclusion, the Court's analysis followed three steps. First, the Court noted that federal legislation implies that tribal courts do not have jurisdiction over non-Indians. ${ }^{85}$ Second, the Court exammed the particular treaty involved in the case for evidence that the tribe had relinquished its jurisdiction over non-Indians. ${ }^{86}$ Finally, the Court concluded that tribal court jurisdiction over non-Indians would be inconsistent with the tribes' status as dependent nations because of the conflicting (and superior) federal interest im protecting its citizens "from unwarranted intrusions on their personal liberty." 87

\footnotetext{
83. 435 U.S. 191, 194 (1978).

84. Id. at 194-95.

85. Id. at 203-06.

86. Id. at $206-08$.

87. Id. at 210.
} 
The Ninth Circuit in Duro v. Reina ${ }^{88}$ and the Eighth Circuit in Greywater v. Joshua ${ }^{89}$ addressed the related issue, whether tribal courts have jurisdiction over nonineinbers, in light of Oliphant's proclanation that "Indian tribes are prohibited from exercising both those powers of autonoinous states that are expressly terminated by Congress and those powers 'inconsistent with their status." "90 Their conflicting applications of the Oliphant opinion are addressed in turn.

\section{A. Duro v. Reina.}

In Duro v. Reina, ${ }^{91}$ the Ninth Circuit held that a nonmenber Indian who had significant contacts with the Salt River Indian Reservation was subject to the criminal jurisdiction of the tribal court for discharging a firearm against another nonmember. ${ }^{92}$ The court initially apphed the jurisdictional analysis set forth in Oliphant, ${ }^{93}$ but ultimately determined that this analysis did not resolve the issue. Evidence both for and against jurisdiction could be found in the treaties and statutes-the first two prongs of the Oliphant analysis. ${ }^{94}$

Moreover, the third prong of the test that focused on the tribe's dependency status was not dispositive. In Oliphant, the Court held that tribal jurisdiction over non-Indians conflicted with the overriding federal interest in protecting personal liberties of U.S. citizens and, therefore, conflicted with the tribe's status as a dependent nation. ${ }^{95}$ The Ninth Circuit, however, found that this federal interest did not dictate the same result in Duro as in Oliphant ${ }^{96}$ since both tribal inembers and nonineinber Indians had been inade U.S. citizens in 1952,97 and no "overriding

88. 851 F.2d 1136 (9th Cir. 1988).

89. 846 F.2d 486 (8th Cir. 1988).

90. Oliphant, 435 U.S. at 208.

91. 851 F.2d 1136 (9th Cir. 1988). This opinion superceded the Ninth Circuit's first opinion reported at 821 F.2d 1358 (9th Cir. 1987). Although both opinions found that the tribe had jurisdiction over the non-member Indian, the revised opinion added an additional ground for the court's holding based on the federal jurisdictional scheme.

92. Id. at 1145. The court framed the issue before it as "a troubling choice between recognizing new restrictions on tribal sovereignty on the one hand, and placing an additional jurisdictional liability upon Indians not members of the tribe whose jurisdiction is in question." Id. at 1139. The question of jurisdiction over non-member Indians had not previously arisen in federal court. The modern day reality of displaced tribes, the heterogenity of present day reservations and the increasing sophistication of tribal courts made it issue. $I d$.

93. 435 U.S. 191, 208 (1978). See supra text accompanying notes $21-22$ (describing Oliphant's triparate test).

94. Duro, $851 \mathrm{~F} .2 \mathrm{~d}$ at 1141.

95. Oliphant, 435 U.S. at 210.

96. Duro, 851 F.2d at 1142.

97. 8 U.S.C. $\$ 1401$ (a) (1982). 
federal interest" precluded tribal court jurisdiction over criminal defendants who concurrently are members of the tribe and U.S. citizens. ${ }^{98}$ Subsequent Supreme Court cases have further confused this issue. Sone of them assume, in dicta, that Oliphant's reasoning should apply to nonmember Indians as well as non-Indians, ${ }^{99}$ whereas others do not. 100

The Duro court explained that "what is more dispositive of this case is the [evidence found in the] federal criminal statutory scheme and its treatment of crimes committed by Indians;" the court reasoned that this treatment established the member/nonmember distinction as umimportant for purposes of criminal jurisdiction. ${ }^{101}$ The federal scheme subjects individuals to prosecution under the federal statutes based on their status as Indians or non-Indians, not based on their membership in the tribe governing the reservation where the offense occurred. ${ }^{102}$ Because tribal jurisdiction over Indians covers everything not granted to the federal governinent, the court reasoned that a tribe's jurisdiction also must depend on an Indian's status as an Indian, and not on whether he is a member of the tribe. ${ }^{103}$

After having determined that the tribal court had not been divested of criminal jurisdiction over nonmembers, the Ninth Circuit then turned to an equal protection analysis to ascertain whether subjecting a nonmember to tribal court jurisdiction would deprive him of equal protection of tribal laws in violation of the Indian Civil Rights Act.104 The

98. Duro, 851 F.2d at 1142. Although this portion of the Duro opinion is confusing, the court seemed to reason that if U.S. citizenship is the dispositive factor in determining whether tribes have been divested of jurisdiction over certain persons, then they would no longer be able to exercise jurisdiction over member Indians since they too are citizens. Such a conclusion would clearly make the firmly established concept of self-governance meaningless. Thus, U.S. citizenship cannot be the dispositive factor.

99. The court cited Merrion v. Jicarilla Apache Tribe, 455 U.S. 130, $171-73$ (1982) (Stevens, J. dissenting) and United States v. Wheeler, 435 U.S. 313, 326 (1978). Duro, 851 F.2d at 1140.

100. The court cited National Farmers Union Ins. Co. v. Crow Tribe of Indians, 471 U.S. 845, 853-55 (1985) and Washington v. Confederated Tribes, 447 U.S. 134, 153 (1980). Duro, 851 F.2d at 1140.

101. Duro, 851 F.2d at 1142.

102. Id. at 1142-43. See infra notes $138-41$ and accompanying text.

103. Id. (citing Arizona ex rel. Merrill v. Turtle, 413 F.2d 683, 686 (9th Cir. 1969)).

104. 25 U.S.C. $\$ 1302$ (1982 \& Supp. V 1987). The Act provides guarantees analogous to those provided in the Constitution's Bill of Rights to those appearing before a tribal court. For example, it guarantees the right against self-incrimination, double jeopardy, and cruel and unusual punishment, as well as the right to equal protection and due process of law. The Act does differ from federal constitutional standards in certain respects. For instance, the sixth amendment's guarantee of the right to counsel imcludes the assurance that an attorney will be provided if the defendant is not able to afford one. The Indian Civil Rights Act, on the other hand, provides that although a defendant is entitled to counsel in every case, it must be at his own expense. 25 U.S.C. \$ 1302(6). 
court found no impermissible racial discrimination ${ }^{105}$ and held that Duro's "significant contacts" with the Tribe--he hived and worked on the Salt River Indian Reservation-were sufficient to justify the tribal court's assertion of criminal jurisdiction. ${ }^{106}$ In using the "minimum contacts" test, the court was extending the rationale of International Shoe Co. v. Washington, in which the Supreine Court held that "minimum contacts" between a nonresident defendant and a state seeking to exercise long arm jurisdiction over the defendant must satisfy due process fairness requirements, ${ }^{107}$ to Indian affairs.

In further support of its conclusion that tribal court jurisdiction over noumembers was a rational exercise of the tribe's sovereignty, the court noted that treating noumembers as members for jurisdictional purposes "would strengthen tribal authority over the reservation"108 and would assure that nonmembers do not fall through the jurisdictional void that often results from inadequate state and federal prosecutions. ${ }^{109}$

B. Greywater v. Joshua.

Greywater v. Joshua involved two meinbers of the Turtle Mountain Band of Chippewa Indians who were charged by the Devils Lake Sioux Tribe under its Tribal Code with possession of alcohol in a motor vehicle, public intoxication, and disorderly conduct. ${ }^{110}$ When the tribal court refused to dismiss the charges for lack of criminal jurisdiction, the defendants filed petitions for writs of habeas corpus in United States district

105. Duro, 851 F.2d at 1144. Since the court concluded that the tribal court's extension of criminal jurisdiction over Duro was not based on race alone, but rather on the "totality of circumstances" as to who qualifies as an Indian, the classification was subject merely to a rationality standard. Id. at 1144-45. For a discussion of the equal protection issue, see Note, Who is an Indian?: Duro v. Reina's Examination of Tribal Sovereignty and Criminal Jurisdiction over Nonmember Indians, 1988 B.Y.U. L. REv. 161, 177-81 (Nimth Circuit's recognition of tribal criminal jurisdiction not limited to a narrow racial classification but is a rational broadening of the definition of who is an Indian); Note, Indian Self-Determination, Tribal Sovereignty, and Criminal Jurisdiction: What About the Nonmember Indian?, 1988 UTAH L. REV. 379, 402-06; Comment, Jurisdiction Over Nonmember Indians on Reservations, 1980 ARIz. ST. L.J. 727, 749-55 (arguing that nonmember Indians must be treated like non-Indians).

106. Duro, 851 F.2d at 1145.

107. 326 U.S. 310,316 (1945).

108. Duro, 851 F.2d at 1145.

109. Id. at 1145-46. The court explained that if the tribal court were denied jurisdiction, only a state court wonld be able to try Duro because his status would be as a non-Indian for jurisdictional purposes. As a practical matter, the court noted, state courts often do not exercise their jurisdiction in cases of this nature; thus, Duro wonld fall through the resnlting jurisdictional void. However, the court failed to recognize that the federal government conld assume jurisdiction in Duro's case under the Major Crimes Act, for murder. See infra notes 143-46 and accompanying text for a discussion of when a jurisdictional void would exist.

110. 846 F.2d 486, 487 (8th Cir. 1988). 
court. The district court dismissed the petitions, and an appeal to the Court of Appeals for the Eighth Circuit followed.

The Eighth Circuit held in Greywater that the tribal court did not have jurisdiction over the nonmember Indians. In considering whether the tribe's sovereign power over nonmembers had been "divested by necessary implication of the Sioux Tribe's status as a dependent nation,"111 the court found that the Supreme Court's analysis in Oliphant compelled it to conclude that the tribal court could not try nonmember Indians. The court reasoned that the overriding federal interest recognized in Oliphant to protect individual liberties of citizens also applied to nonmenber Indians. ${ }^{112}$

In support of its holding, the court rehed on languagc in Supreme Court cases decided after Oliphant which buttress its assertion that nonmembers were included in Oliphant's holding. The first case that the court discussed at length was United States v. Wheeler. ${ }^{113}$ The Greywater court pointed out that the Supreme Court in Wheeler explicitly referred to the tribes' power over "1nembers" when discussing the retained sovereign powers of Indian tribes. ${ }^{114}$

Similarly, the court cited Washington $v$. Confederated Tribes of the Colville Indian Reservation in support of its decision. The Court in Colville allowed a state to tax Indians living on the reservation who were not enrolled in the tribe, on the grounds that the tax would not undermine tribal self-government since "nonmembers are not constituents of the governing Tribe." 115 Einploying reasoming similar to Colville, the Eighth Circuit held that the exercise of criminal jurisdiction over the nonmember petitioners was not necessary to guarantee the tribe's right to selfgovernment because the petitioners could not vote, hold tribal office, sit on tribal juries, or siguificantly share in tribal disbursements. ${ }^{116}$

\section{ApPlication of Oliphant's Three-Part Test of Diminished SOVEREIGNTY TO CRIMINAL JURISDICTION OVER NONMEMBER INDIANS}

As stated above, Indian tribes retain those aspects of sovereignty that have not been withdrawn either exphicitly by treaty or congressional

111. Id. at 489. Because the court found that Congress has not explicitly terminated the criminal jurisdiction of the Devil Lake Sioux Tribe over nonmember Indians, it limited its anaysis to the third prong of the Oliphant test. Id.

112. Id. at 493 (citing Oliphant v. Suquamish Indian Tribe, 435 U.S. 191, 210-11 (1978)).

113. 435 U.S. 313 (1978).

114. Greywater, 846 F.2d at $491-92$.

115. 447 U.S. 134, 161 (1980).

116. Greywater, 846 F.2d at 493. 
statute, or implicitly as a result of their dependent status. ${ }^{117}$ The following discussion addresses each of these areas that alter tribal soverignty as they apply to the inherent authority of a tribe to exercise criminal jurisdiction over nonmember Indians who have allegedly committed a crime on the tribe's reservation. ${ }^{118}$ As both the Duro court and the Greywater court concluded, and as illustrated below, the first two inquiries clearly do not preclude exercise of such jurisdiction. ${ }^{119}$ The dependent status question, however, deinands careful attention. Neither the Eighth nor the Ninth Circuits adequately explored this question as the Oliphant analysis requires. Therefore, the remainder of this Note concentrates on this final inquiry.

\section{A. Treaty Analysis.}

As recognized by both the Eighth Circuit in Greywater ${ }^{120}$ and the Ninth Circuit in Duro, ${ }^{121}$ the treaties executed between the United States and the Indian tribes do not divest the Indian tribes of their inherent power to exercise jurisdiction over nonmember Indians. ${ }^{122}$ The treaties, which were primarily concerned with establishing peaceful, friendly relations between the Indian tribes and the federal government, simply did not distinguish the treatment of nonmember Indians from other Indians. Rather, they established a procedure by which crimes that involved U.S. citizens and Indians would be punished peacefully in an effort to avoid private retaliation. ${ }^{123}$

A typical treaty from the earliest period of treaty-making witl the Indians provided that if any Indian or person residing among them committed a crime against a U.S. citizen, the tribe was obhiged to "deliver

117. See supra notes $21-22$ and accompanying text.

118. As pointed out by the Duro court, some level of minimum contact with the reservation is necessary in order for a tribal court to claim jurisdiction over a nonmember. Duro v. Reina, 851 F.2d 1136, 1144 (9th Cir. 1987). Without such minimal contact, a tribe could not claim that jurisdiction is necessary for adequate self-governance. Furthermore, it would be a weak argument to propose in that case that tribal imterest in jurisdiction is any stronger than the state or federal interest.

119. Duro, 851 F.2d at 1141; Greywater, 846 F.2d at 489.

120. 846 F.2d at 489 (Congress has not explicitly terminated the Devils Lake Sioux Tribe's authority to prosecute nonmember Indians).

121. $851 \mathrm{~F} .2 \mathrm{~d}$ at 1141 ("[T]he historical evidence is equivocal on the question of whether tribal court jurisdiction extends to nonmember Indians.").

122. The signing of new treaties ceased in $\mathbf{1 8 7 1}$ with the passage of the Indian Appropriations Act, which included a provision stating that Indian tribes would no longer be recognized as independent nations with whom the United States could contract by treaty. Act of March 3, 1871, ch. 120,16 Stat. 544, 566 (current version at 25 U.S.C. $\$ 71$ (1982)).

123. See, e.g., Treaty with the Quapaws, Aug. 24, 1818, art. 6, 7 Stat. 176, 177-78 (where "the friendship ... between the United States and the said tribe or nation, should be interrupted by the misconduct of individuals," the offender was to be "dehiver[ed] up" for punishment). 
him ... up to be punished according to the laws of the United States."124 Similarly, if a U.S. citizen committed a crime against an Indian, he was to be punished "in the sanie nianner as if the [crime] had been coinmitted ... against a citizen [of the United States]." 125 These early treaties nrade no distniction between Indians of the signatory tribe and Indians of other tribes.

Later treaties included similar provisions, yet they often referred explicitly to the tribes of signatory Indians. ${ }^{126}$ These later treaties resulted in federal jurisdiction over crimes that specifically involved meinber Indians and U.S. citizens. ${ }^{127}$ However, no treaty stipulated that the federal government would have jurisdiction over crimes involving nonmember and member Indians. That issue was simply not addressed.

Several of the later treaties did provide that disputes between the signatory tribe and soine otlier tribe would be subject to federal jurisdiction. ${ }^{128}$ A typical treaty provision of this sort was involved in Ex parte Crow Dog. 129 The treaty provision stated:

If bad men among the Indians shall commit a wrong or depredation upon the person or property of anyone, white, black or Indian, subject to the authority of the United States and at peace therewith, the Indians herein named solemnly agree that they will, upon proof inade to their agent and notice by him, deliver up the wrong-doer to the United States to be tried and punisled according to its laws .... ${ }^{130}$

It has been argued that sucli provisions made no sense unless they meant the federal government was responsible for punishing crimes coinmitted by an Indian against a member of a different tribe. ${ }^{131}$ On the other hand, the apparent purpose behind these provisions was to avoid tribal war in the event of an intertribal dispute. For example, the treaty with the Unpquas and Calapooias stated: "Nor will [tlie signatory tribe] make war on any other tribe except in self-defense, but will subinit all

124. Treaty with the Cherokees, July 2, 1791, art. 10, 7 Stat. $39,40$.

125. Id. art. 10, at 41 .

126. See, e.g., Treaty with the Quapaws, Aug. 24, 1818, art. 6, 7 Stat. 176, 177 (offenders of the "said tribe or nation" were to be "dehiver[ed] up" for punishment).

127. See Comment, supra note 105, at 737-38. If the treaty did not expressly require that federal law should apply, these treaty provisions necessarily implied that it should because tribal court systems at that time were not sophisticated. See Oliphant v. Suquamish Indian Tribe, 435 U.S. 191, 197 (1978) (noting that few tribes had formal court systenus in the 19th century).

128. See, eg., Treaty with the Umpquas and Calapooias, Nov. 29, 1854, art. 8, 10 Stat. 1125, 1127 (providing that the signatory tribes would not "make war on any other tribe except in selfdefence, but [would] submit all matters of difference . . . to the government of the United States").

129. 109 U.S. 556 (1883) (ruling that district court was without jurisdiction because federal legislation, which excluded crimes conimitted in Indian country by one Indian against another, had not been repealed).

130. Id. at 563 (quoting Treaty with the Sioux Indians, Apr. 29, 1868, art. 1, 15 Stat. 635, 635).

131. See Conment, supra note 105 , at $737-41$. 
matters of difference between them and other Indians to the government of the Umited States . . . ."132 Individual crimes between members and nonmembers were not necessarily the type of dispute these treaties addressed. Therefore, the tribes arguably retamed jurisdiction over nonmembers for crimes committed on their reservations. ${ }^{133}$

The courts have never addressed the question whether these treaties awarded the federal government criminal jurisdiction over nonmember Indians. Yet the Attorney General in 1883 issued an opinion, Crimes Committed Against Indians, ${ }^{134}$ rejecting the argument that the government had jurisdiction over nonmembers. Furthermore, some treaties exphicitly recognized tribal court jurisdiction over any person (including nonmembers as well as non-Indians) who committed a crime within the tribe's territory. ${ }^{135}$

Courts will not divest the inherent sovereignty of the Indian tribes based on treaty authority without express imtent in treaty language. ${ }^{136}$ Because of the lack of express intent in the treaties to divest the tribes of criminal jurisdiction over nonmember Indians, jurisdiction cannot be denied under the first prong of the Oliphant test.

132. Treaty with the Umpquas and Calapooias, Nov. 29, 1854, art. 8, 10 Stat. 1125, 1127.

133. One commentator has argued that an analysis of the treaties between the U.S. and the Indian tribes reveals that non-members were treated like non-Indians. Therefore, according to the Comment, a strong argument can be set forth that nonmembers are not subject to tribal court jurisdiction, since non-Indians are not. Comment, supra note 105 , at 735 n.59, 737-41. However, because the intent behind the treaty provisions providing for federal jurisdiction over intertribal disputes was most likely to prevent intertribal warfare-no evidence to the contrary exists-the treaties cannot be read to have divested tribal courts of jurisdiction over nonmember Indians for crimes committed on the reservations. Moreover, a settled principle of treaty interpretation is that "[d]oubtful expressions are to be resolved in favor of the weak and defenseless people who are the wards of the nation, dependent upon its protection and good faith." McClanahan v. State Tax Comm'n, 411 U.S. 164, 174 (1973) (quoting Carpenter v. Shaw, 280 U.S. 363, 367 (1930)).

134. 17 Op. Att'y Gen. 556 (1883). This opinion was authored by the Solicitor General and later approved by the Attorney General.

135. See, e.g., Treaty with the Choctaws and Chickasaws, June 22, 1855, art. 6, 11 Stat. 611, 612 ("Any person duly charged with a criminal offense against the laws of eitlier the Choctaw or the Chickasaw tribe, and escaping into the jurisdiction of the other, shall be promptly surrendered, upon the demand of the proper authorities of the tribe, within whose jurisdiction the offense sliall be alleged to have been committed.").

136. See Oliphant v. Suquamish Indian Tribe, 435 U.S. 191, 208 n.17 (1978). But see Comment, supra note 105, at 737-42 (asserting tiat the treaties did divest tribes of criminal jurisdiction over nonniember Indians). 


\section{B. Statutory Analysis.}

Statutes, as discussed in section III, may have the effect of divesting a tribe of some aspects of sovereignty. ${ }^{137}$ However, Congress has not enacted a statute that expressly removes criminal jurisdiction over nonmember Indians. Federal Indian law fails to distinquish between member and nonmember Indians. The only statute that defines "Indian," the Indian Reorganization Act of 1934, specifically characterizes "Indians" as "all persons of Indian descent who are ineinbers of any recognized tribe now under Federal jurisdiction ...."138 Moreover, all statutes providing services to Indians extend their protections and benefits to all Indians, whether they reside on their own tribes' reservation or on the reservation of some other tribe. ${ }^{139}$

Similarly, the two statutes that specifically address the allocation of criminal jurisdiction in Indian country, the General Crimes Act and the Major Crimes Act, apply to all Indians, not just to member Indians of the tribe in question. ${ }^{140}$ As explained by the Duro court, the relevant question for the purposes of determining federal jurisdiction under both of these statutes is whether the Indian who has committed a crime "is a member of a tribe that has a special relationship with the federal governinent, not whether the defendant happens to have a relationship with the tribe governing the reservation where the offense occurred." 141

Statutory authority also does not implicitly divest tribes of criminal jurisdiction over nonmembers. As explamed more fully in section III, criminal jurisdiction over Indians in Indian country is as follows: (1)

137. Oliphant, 435 U.S. at 208. If there is a conflict between a statute and a treaty, the general rule is that the one later in time governs. See Thomas v. Gay, 169 U.S. 264, 271 (1898); The Cherokee Tobacco, 78 U.S. (11 Wall.) 616, 621 (1871).

138. 25 U.S.C. $\$ 479$ (1982).

139. See. e.g., Indian Reorganization Act, 25 U.S.C. $\$ 4$ (1982); Indian Self-Determination Act and Educational Assistance Act, 25 U.S.C. $\$ 1901$ (1982); Indian Child Welfare Act, 25 U.S.C. $\S 1901$ (1982); Indian Financing Act, 25 U.S.C. $\$ 1451$ (1982); cf. 25 C.F.R. $\$ 11.2$ (a) (1989) (regulatory scheme establishing courts of Indian Offenses provides that these courts "shall havc jurisdiction over all offenses . . . when committed by any Indian, within the reservation or reservations for which the court is established").

140. See supra notes $64,70$.

141. Duro v. Reina, 851 F.2d 1136, 1142-43 (9th Cir. 1988); see also United States v. Kagama, 118 U.S. 375, 383 (1886) (finding the Major Crimes Act applies as long as the Indian is of some federally recognized tribe); United States v. Burland, 441 F.2d 1199, 1203 (9th Cir. 1971) (General Crimes Act applied to member of the Confederated Salish and Kouterai Tribes who committed crime on Flathead Reservation); Ex Parte Pero, 99 F.2d 28, 30-32 (7th Cir. 1938) (Indian's relationship to federal government supported federal jurisdiction); cf. United States v. Heath, 509 F.2d 16, 19-20 (9th Cir. 1974) (Klamath Indian was not subject to federal jurisdiction under Major Crimes Act for killing a member of the Warm Springs Reservation because her tribe had been "terminated" from federal supervision; there was no indication that federal jurisdiction was lacking because she was not a member of the Warm Springs Tribe); Arizona ex rel. Merrill v. Turtle, 413 F.2d 683, 686 (9th Cir. 1969) (federal government gave power to tribe to govern mothers due to its relationship). 
federal courts have jurisdiction over all Indians committing major crimes on reservations; (2) tribal courts have exclusive jurisdiction over all Indians (on reservations in states not governed by Public Law 280 or similar legislation) committing offenses not covered by the Major Crimes Act against other Indians; and (3) tribal courts and federal courts have concurrent jurisdiction over all Indians committing offenses not covered by the Major Crimes Act against non-Indians. ${ }^{142}$

If a tribal court does not have jurisdiction over nonmember Indians for non-major crimes involving other Indians in Indian country, it is important to realize that no court will have jurisdiction. The federal courts do not have jurisdiction over such crimes, for the General Crimes Act explicitly excepts from jurisdiction Indians committing crimes against other Indians. ${ }^{143}$ Similarly, state courts that do not act under the auspices of Public Law 280 or similar statutes have no jurisdiction over Indians. ${ }^{144}$ For a nonmember Indian to be tried in a state court, she would have to be considered a non-Indian. It seems farfetched to assume that Congress intended that a nonmember Indian should be divested of his classification as an "Indian" for the sole purpose of trying his criminal act in a state court. ${ }^{145}$ Further, Congress would not knowingly create a jurisdictional void. ${ }^{146}$ The necessary conclusion is that federal law does not deprive the Indian tribes of criminal jurisdiction over nonmeinber Indians.

\section{Inconsistency with the Tribe's Dependent Status Analysis.}

After the Supreme Court in Oliphant determined that a tribal court did not have criminal jurisdiction over non-Indians based on the relevant treaty or statutes, the Court turned to a third line of analysis. This third prong added a new dimension to the traditional inherent sovereignty analysis previously established by the Court. ${ }^{147}$ Prior to Oliphant, tribal

142. See supra notes $57-81$ and accompanying text.

143. See supra note 66 .

144. See supra notes $73-82$ and accompanying text; $c f$. State v. Lohnes, 69 N.W.2d 508, 517 (N.D. 1955) (holding that under state law the state had not consented to jurisdiction over Indians despite the fact that Congress had passed Act of May 31, 1946, 60 Stat. 229, which granted the state concurrent criminal jurisdiction over Indians on the Devils Lake Reservation).

145. A state would have even less interest in a crime committed on a reservation within its territory than the federal government. Under the current self-determination policy, tribal sovereignty is analogous to state sovereignty. Just as one state cannot intrude upon the internal affairs of another state, a state cannot interfere with tribal self-government. However, the federal government's relationship with the Indian tribes is "that of a ward to his guardian," Cherokee Nation v. Georgia, 30 U.S. (5 Pet.) 1, 17 (1831), thus putting the federal government in a position to exercise more control over Indian affairs than a state can exercise.

146. See Duro v. Reina, 851 F.2d 1136, 1145-46 (9th Cir. 1988).

147. Oliphant v. Suquamish Indian Tribe, 435 U.S. 191, 208 (1978). 
sovereignty was defined according to the criteria set forth in Worchester v. Georgia. ${ }^{148}$ Under Worchester, Indian tribes retained those aspects of internal sovereignty they possessed prior to conquest, except for those powers expressly withdrawn by treaty or statute. ${ }^{149}$ Relying on two cases froin the Marshall era, the Oliphant Court expanded the traditional analysis to include a concern for the "inconsistency [of the sovereignty of tribes] with their dependent status."150 In the first of these two cases, Johnson v. M'Intosh, the Court identified an intrinsic limitation on the tribes' abilities to dispose of their lands at will. ${ }^{151}$ In the second case, Cherokee Nation v. Georgia, the Court explained that "any atteinpt [by foreign nations] to acquire [Indian lands], or to forn a political connexion with [the Indians], would be considered by all as an invasion of our territory and an act of hostility."152

The Oliphant Court interpreted these two decisions to stand for the proposition that once the Indian tribes came under the dominion of the United States, "their exercise of separate power [was] constrained so as not to conflict with the interests of th[e] overriding sovereignty" of the United States. ${ }^{153}$ Based on this analysis, the Oliphant Court found that when the United States' interest to protect its citizens "froin unwarranted intrusions on their personal hiberty" comes into conflict with the tribes' conipeting interest to try non-Indian citizens who have coninitted crimes on their reservations, the Indian tribes' inherent sovereignty must yield. 154

The question reniains whether the United States' interest in protecting its citizens from unwarranted intrusions on their personal liberty at the expense of tribal court jurisdiction extends to nonmeinber Indians as well as non-Indians. To answer this question, this Note first reviews the post-Oliphant caselaw of the Supreine Court. It then examines current congressional and executive policy regarding the status of the Indian tribes. Finally, finding neither of the former two sources of authority determinative, this Note examines whether the assertion of tribal court criminal jurisdiction over nonmenbers is indeed inconsistent with the tribe's dependent status in hight of the present-day realities of tribal neinbership.

\footnotetext{
148. 31 U.S. (6 Pet.) 515, 576 (1832).

149. Id.

150. See Oliphant, 435 U.S. at 208.

151. 21 U.S. (8 Wheat.) 543,574 (1823).

152. 30 U.S. (5 Pet.) 1, 16 (1831).

153. Oliphant, 435 U.S. at 209.

154. Id. at 210.
} 
1. Post-Oliphant Dicta Regarding the Treatment of Nonmember Indians. As the Nintl Circuit opinion in Duro demonstrates, the Supreine Court cases after Oliphant equivocate on the treatinent of nonmeinber Indians for jurisdictional purposes. ${ }^{155}$ While soine cases have assumed that nonmeinbers are the same as tribal inembers, language in other cases suggests that nonmennbers are more like non-Indians. A survey of these cases indicates thiat the Court has used the terms "member/ nonmember" and "Indian/non-Indian" imprecisely and lias not based its holdings on such distinctions. This Note therefore concludes that the Court lias yet to extend Oliphant's lolding-that tribal courts lack jurisdiction over non-Indians-to cover nonmember Indians.

The Eiglith Circuit in Greywater relied on United States v. Wheeler, ${ }^{156}$ decided only sixteen days after Oliphant, to support the extension of Oliphant's holding to apply to nonmember Indians. ${ }^{157}$ 'In Wheeler, the Supreme Court considered whether the double jeopardy clause of the fifth amendment ${ }^{158}$ barred the federal government froin prosecuting a tribal member under the Major Crimes Act who had been convicted previously of a lesser-included offense in a tribal court. ${ }^{159}$ After concluding that a tribe's power to punish its members was an imphicit part of its retained sovereignty, the Court lield that "[s]ince tribal and federal prosecutions are brought by separate sovereigus, they are not 'for the same offense,' and the Double Jeopardy Clause tlius does not bar one when the other has occurred."160 Throughout its discussion, the Court referred to a tribe's sovereigu power over tribal members. For example, the Court described the powers of self-government as "involv[ing] only the relations among members of a tribe."161 Moreover, when citimg the lolding of Oliphant, the Court stated that tribal courts "cannot try nonmembers in tribal courts." 162

The Greywater court reasoned that the Supreme Court's use of the terms "ineinbers" and "nonmembers" in Wheeler was a deliberate clarification of its prior liolding in Oliphant; ${ }^{163}$ tribal court jurisdiction over nonmembers includes Indians as well as non-Indians, and is thus inconsistent with a tribe's dependent status. If the Greywater court's conclusion, that Wheeler's language extends Oliphant's lolding to nonmeinber

155. Duro v. Reina, 851 F.2d 1136, 1141 (9th Cir. 1988).

156. 435 U.S. 313 (1978).

157. Greywater v. Joshua, 846 F.2d 486, $489-92$ (8th Cir. 1988).

158. U.S. CONST. amend. V.

159. Wheeler, 435 U.S. at 314.

160. Id. at 329-30.

161. Id. at 326.

162. $I d$.

163. Greywater v. Joshua, 846 F.2d 486, 489-92 (8th Cir. 1988). 
Indians, is correct, then clearly there would be no need for further discussion of whether a tribal court has jurisdiction. This Note argues, however, that the Eighth Circuit's reasoning is flawed for two reasons.

First, the Supreme Court is not likely to extend its holding in Oliphant to include the additional category of nonmember Indians, who constitute a significant portion of most reservations, ${ }^{164}$ without a more deliberate and explanatory discussion of its reasons for such an extension. For mstance, in National Farmers Union Insurance Companies $v$. Crow Tribe of Indians, the Court refused to extend the holding of Oliphant to mclude civil jurisdiction over non-Indians without "a careful examination of tribal sovereignty, the extent to which that sovereignty has been altered, divested, or dimimished, as well as a detailed study of relevant statutes, Executive Branch policy as embodied in treaties and elsewhere, and administrative or judicial decisions." 165 Because neither the tribal court nor the district court had employed such a careful examination, the Court remanded the case to the tribal court to analyze whether it retamed civil jurisdiction over non-Indians in light of these inore demanding criteria.166 Applying Oliphant to criminal jurisdiction over nonmember Indians tlius would seem to require, at a mimimum, the same "careful examination."

The second reason the Greywater court's interpretation of Wheeler suffers arises from the Court's reasoning in Wheeler. Although the Court in Wheeler failed to explicitly include nonmember Indians in its discussion of the tribes' retamed powers over their own inembers, ${ }^{167}$ and the Court specifically did say that "nonmembers" may not be tried by a tribal court, closer analysis shows that little significance should be attaclied to the Court's use of the category "noimiembers" for purposes of jurisdiction over nonmember Indians cominitting crimes on the reservation. The question before the Court in Wheeler was whether a tribe member was deprived of due process. Understandably, the Court's detailed discussion of the retained powers of sovereignty, including the tribes' power to "prescribe and enforce internal criminal laws,"168 establislied that a tribal court has inherent power over meinbers of its own

164. See Bureau of the Census, U.S. Dep't of Commerce, 1980 Census of Population REPORT: AMERICAN INDIANS, EsKimos, AND AleUts, vol. 2, table 4 (1985) (13\% of persons residing on Indian reservations are not enrolled in the tribe); id. at table 7 (23.1\% of Indians one year and older did not always reside on the reservation, inplying that they have resided elsewhere, perhaps on other reservations and may not have been born meinbers); see also infra notes 175-81 and accompanying text.

165. 471 U.S. $845,855-56$ (1985).

166. Id. at $856-57$.

167. United States v. Wheeler, 435 U.S. 313, 322-26 (1978).

168. Id. at 326. 
tribe. Nothing about the facts in Wheeler indicate that the Court gave attention to the distinction between ineinbers and nonmeinber Indians with significant contacts to the reservation. Just as easily, one can conclude that by "nonmember" the Court meant "non-Indian," or alternatively nonmember Indian without significant contacts with the reservation. Evidence of the continuing ambiguity is also found in the Court's plainly imprecise use of the terms "nonmeinber" and "non-Indian" in subsequent opimions. ${ }^{169}$ The separate and clearly distinct issue of jurisdiction over nonmembers as defined in this Note was never explicitly addressed in any of the Court's opimions, nor was it resolved by implication.

The Greywater court rehed on Washington v. Confederated Tribes of the Colville Indian Reservation ${ }^{170}$ as further evidence that the Court's use of the term "non-Indian" in Oliphant was intended to include nonmennber Indians. ${ }^{171}$ Colville is the only Supreme Court case in which an Indian's status as a noninember was specifically apphicable to the Court's holding. The important issue im the case for the purposes of this Note was whether the state of Washington possessed the power to apply a sales and cigarette tax to nonmeinber Indians. ${ }^{172}$ Finding that the state's imterest in taxing nonmembers outweighed any tribal interest to prevent such a tax, the Court held that Washington indeed possessed this taxing power. The Court based its holding, in part, on the premise that allowing the state to tax nonmembers would not "contravene the primciple of tribal self-government" since the nonmember purchasers "are not constituents of the governing tribe" and do not "have a say in tribal affairs or significantly share in tribal disbursements." 173 The Court declared, "for inost practical purposes those Indians stand on the same footing as nonIndians resident on the reservation." 174

Although the case held that nonmember Indians do not enjoy the same state-tax immumity as member Indians, the Court's analysis in Colville may support-rather than detract froin-the conclusion that tribal courts have criminal jurisdiction over nonmember Indians. Criminal jurisdiction is one area in which nonmembers do not "stand on the same footing as non-Indians." A tribe has an undeniably strong interest in nraintaining peace on its reservation. To maintain peace, the tribe's

169. See infra notes $170-82$ and accompanying text.

170. 447 U.S. 134 (1980).

171. Greywater v. Joshua, 846 F.2d 486, $492-93$ (8th Cir. 1988).

172. Confederated Tribes of the Colville Indian Reservation v. United States, 447 U.S. 134, 138 (1980).

173. Id. at 161 .

174. Id. 
power must extend to all Indians who reside on the reservation or significantly participate in reservation activities, whether they are members or nonmembers. Simce criminal jurisdiction is intimately related to effective self-governance, the tribal courts' interest clearly would seem to outweigh any state or federal interest in pumishing Indian defendants. ${ }^{175}$ Unlike permittimg a state to tax nonmember Indians, divesting tribes of jurisdiction over nonmember Indians who have committed crimes on the reservations would "contravene the principle of tribal self-government." Indeed, it is difficult to conceive of any tribal interest that would carry greater weight for purposes of self-government and domestic tranquility.

Finally, throughout its discussion of the other issues presented in Colville, ${ }^{176}$ the Court imprecisely and interchangeably used the terins "non-Indian" and "nonmember." For example, in describing the retained sovereignty of the Indians to tax "non-Indians" on their reservations, the Court quoted an opimion of the Solicitor of the Department of the Interior that described the tribes' taxing power "over nonmembers, so far as such nonmembers may accept privileges of trade, residence, etc. ...."177 In other words, when specifically confronted with the problem of treatment of nonmembers, the Court referred to them as "Indians resident on the reservation but not enrolled in the governing Tribe"; 178 yet when not specifically addressing the status of nonmeinbers, the Court used the terins non-Indians and nonmembers interchangeably.

Another case demonstrating the Supreme Court's indiscriminate use of the terms "non-Indian" and "nonmember" is Merrion v. Jicarilla Apache Tribe. ${ }^{179}$ The issue in Merrion was whether the tribe had the power to impose an oil and gas severance tax on non-Indians. In upholding the tribe's power to tax as a power derived froin its powers to exclude non-Indians from its reservation, the Court explained:

When a tribe grants a non-Indian the right to be on Indian land, the tribe agrees not to exercise its ultimate power to oust the non-Indian as long as the non-Indian complies with the mitial conditions of entry. However, ... . [a] nonmember who enters the jurisdiction of the tribe remains subject to the risk that the tribe will later exercise its sovereign power. The fact that the tribe chooses not to exercise its power to tax

175. By contrast, in Colville, the Court found "that the State's interest in taxing [nonmembers] outweighs any tribal interest that may exist in preventing the State from imposing its taxes." Id. at 161.

176. The other issues before the Supreme Court in Colville were: 1) whether the appeal was properly before the Court; 2) whether Washington's motor vehicle and motor home, camper and trailer taxes could be imposed on members; and 3) whether Washington lawfully asserted civil and criminal jurisdiction over the Makahand Lummi Indian Reservations. Id. at 145, 162, 164.

177. Id. at 153 .

178. Id. at 160 .

179. 455 U.S. 130 (1982). 
when it initially grants a non-Indian entry onto the reservation does not permanently divest the tribe of its authority to inipose such a $\operatorname{tax} .180$

Surely, the Court was referring to the same class of persons when it mentioned "non-Indian" and "nonmember" in this opinion.

Similarly, in Montana v. United States, ${ }^{181}$ the Court discussed the inherent powers of Indian tribes in the context of its holding that the Crow Tribe did not have the power to regulate hunting and fishing on non-Indian lands within boundaries of the reservation. The Court noted:

[I] $\mathrm{n}$ addition to the power to punish tribal offenders, the Indian tribes retain their inherent power to determine tribal nienibership, to regulate domestic relations among members, and to prescribe rules of inheritance for members . . . . But exercise of tribal power beyond what is necessary to protect tribal self-government or to control internal relations is inconsistent with the dependent status of the tribes, and so cannot survive without express congressional delegation. ${ }^{182}$

Again, the use of the word "members" instead of "those Indians participating on the reservation," or similar language inılying tribal authority over both nonmember and member Indians, should not be imterpreted as significant in hight of the issue before the Court-the Crow Tribe's power over non-Indian land. Further, while regulatory power over non-Indian land falls "beyond what is necessary to protect tribal self-government or to control internal relations," criminal jurisdiction over nonmembers residing on the reservation is necessary to control internal relations.

In hight of the Supreme Court's imprecise use of the terms non-Indian and nonmember, the Greywater court's conclusion that Wheeler and Colville extend Oliphant to exclude nonmember Indians from tribal court criminal jurisdiction seems at best tenuous.

2. Current Federal Policy. The current federal pohicy guiding the federal government's relationship to the Indians is embodied in the Indian Self-Determination and Education Assistance Act. ${ }^{183}$ The thrust of the self-determination pohicy is that because the Indians are a separate people with a uinque cultural background, they should be encouraged to protect and develop their own customs, system of government, laws, and judicial systein. ${ }^{184}$ The purpose of the Act is clearly set forth in the statutory language:

180. Id. at 144-45 (emphasis added).

181. 450 U.S. 544 (1981).

182. Id. at 564 (citations omitted); see also Rice v. Rehner, 463 U.S. 713, 720-21 \& n.7 (1983) (because regulating sales to nonmembers or non-Indians does not interfere with the tribe's self-government, the tribe is subjected to the state regulations unless Congress has pre-empted such action).

183. 25 U.S.C. § 450f-n (1983 \& Snpp. 1989).

184. Cheyenne River Sioux Tribe v. Kleppe, 424 F. Supp. 448 (1977). 
the prolonged Federal domination of Indian service prograins has served to retard rather than enhance the progress of Indian people and their commumities by depriving Indians of the full opportunity to develop leadership skills crucial to the realization of self-governinent, and has denied to the Indian people an effective voice in the planning and implementation of programs for the benefit of Indians which are responsive to the true needs of Indian communities . . . ${ }^{185}$

The Indian Self-Determination and Education Assistance Act has its roots in several eartier congressional acts. The Tribal Federal Jurisdiction Act of $1966^{186}$ einpowered tribes to sue on their own behalf to enforce their constitutional, treaty, or statutory rights. The American Indian Religious Freedom Act ${ }^{187}$ prohibits federal action from impairing the Indians' religious freedoin, and the Indian Child Welfare Act of $1978^{188}$ granted tribes and Indian families a greater role in Indian child placement. In addition, the American Indian Policy Review Coinmission was established by Congress in 1975 to review federal Indian policy and to consider "alternative inethods to strengthen tribal government."189

Like Congress, the executive branch supports Indian self-determination. As President Reagan stated in his policy stateinent on Indian affairs: "This administration intends to restore tribal governments to their rightful place among the governments of this nation and to enable tribal governments . . . to resume control over their affairs."190

Recognition of tribal court jurisdiction over nonmenner Indians who are hiving on the reservation or otherwise have significant ties to the reservation, is entirely compatible with the current congressional and executive policy regarding Indian self-determination. Such jurisdiction provides tribes with greater control over the affairs of their reservations. In fact, further restriction of the tribes' sovereignty by limiting their criminal jurisdiction over nonmeinbers would contravene congressional and executive policy.

185. 25 U.S.C. $\$ 450(a)(1)$ (1983).

186. Pub. L. No. 89-635, $\$ 1$ (codified at 28 U.S.C. $\$ 1362$ (1982)).

187. Pub. L. No. 95-341, 92 Stat. 469 (codified in part at 42 U.S.C. $\S 1996$ \& note).

188. Pub. L. No. 95-608, 92 Stat. 3069 (codified at 25 U.S.C. $\$ \S 1901-03$ (1982)).

189. $\S 2(6)$, Pub. L. No. 93-580, 88 Stat. 1910, 1912 (1975) (not codified but set forth in full at 25 U.S.C. $\S 174$ note).

190. Presidential Statement on Indian Policy, 19 WeEkLy Comp. Pres. Doc. 98, 101 (Jan. 24, 1983); see also President Nixon's Message to the Congress Transmitting Recommendation for Indian Policy, H.R. Doc. No. 363, 91st Cong., 2d Sess. (1970):

It is long past time that the Indian policies of the Federal government began to recognize and build upon the capacities and insights of the Indian people. Both as a matter of justice and as a matter of enlightened social policy, we must begin to act on the basis of what the Indians themselves have long been telling us. The time las come to break decisively with the past and to create the conditions for a new era in which the Indian future is determined by Indian acts and Indian decisions. 
3. Practical Considerations. Under Oliphant's dependent status analysis, ${ }^{191}$ a court must determine whether a particular exercise of sovereignty by the Indian tribes conflicts with an overriding federal interest. As poimted out im the preceding sections, neither the Supreme Court's treatment of nonmember Indians nor federal policy precludes tribes from maintaining criminal jurisdiction over nonmembers closely associated with their reservations. This section explores the practical considerations involved in tribal membership and nonmembership, as they relate to Indian self-governance, to determine whether recognizing tribal court criminal jurisdiction over nonmember Indians who have significant contacts with the reservation is necessary for self-governance. If criminal jurisdiction is necessary for effective self-governance, then it is difficult to imagine a federal interest that would override the tribes' significant interest in exercising that jurisdiction.

The court in Greywater noted that the Indian tribes' criminal jurisdiction over nonmembers "is of a completely different character than their broad power to control internal affairs." 192 The court based its assertion on the principle that a sovereign should govern only those who have consented to its governance. Since nonmembers do not actively participate in the government of the tribe, the court concluded that a tribe's authority over them is "appropriately limited."193

The fact that nonmember Indians do not have a say in tribal affairs to the same extent as tribal members ${ }^{194}$ does not necessarily justify denying tribal courts jurisdiction over them in criminal cases. Aliens, who do not enjoy the duties and privileges of U.S. citizenship, are nevertheless subject to its laws. ${ }^{195}$ Similarly, when a resident of one state commits a crime in another state, the state where the crime occurred has the power to try the nonresident defendant and, if necessary, to seek his extradiction from his state of residence. ${ }^{196}$ When an Indian who is not technically enrolled in a tribe enjoys the benefits of life on a particular reservation (and even might not have contact with any other reservation), it is appropriate that the tribal government has some control over him.

191. See supra notes 147-53 and accompanying text.

192. Greywater v. Joshua, 846 F.2d 486, 493 (8th Cir. 1988).

193. Id.

194. Id. at 493; Duro v. Reina, 851 F.2d 1136, 1145 (9th Cir. 1988).

195. See, e.g., Restatement (ThiRd) OF Foreign Relations LAW of the UNITEd States $\S 422(1)$ (1986) ("A court in the United States may try a person only for a violation of United States law, not for violation of the penal law of a foreign state.").

196. U.S. CONST. art. IV, $\S 2$. 
The Supreme Court has held that the need for internal control does not automatically invest a tribal court with power over non-Indians. ${ }^{197}$ The Greywater court found it "anomalous" that nonmeinbers should be subject to a tribe's jurisdiction while non-Indians are not, since non-Indians and nonmembers are both present in significant numbers on Indian reservations. ${ }^{198}$ However, while federal law draws a bright-line distinction between Indians and non-Indians, it does not distinguish between inember and nonmember Indians. 199

Further, the Greywater court's focus is the opposite of what it ought to be. The jurisdiction question should not be, as the Eighth Circuit apparently assumes, how far tribal court jurisdiction may extend. Rather, the proper inquiry is how far may federal courts infringe on the inherent sovereignty of the tribes in the absence of Congress's express divestment of tribal sovereignty. When no conflicting federal interest requires the curtailment of any particular power of an Indian tribe, no justification exists for doing so. 200 Certainly the federal government has an interest in assuring that a criminal is tried and pumished if gnilty of a "major" crime in Indian country, whether the defendant is an Indian or a non-Indian. When a major crime is not involved, however, Congress has not divested the tribal courts of jurisdiction over "Indians." This supports the conclusion that any federal interest in a crime committed by a nonmember on a reservation would not outweigh a tribe's interest in selfgovernance. 201

In addition to the apparent absence of an overriding federal interest that precludes criminal court jurisdiction over nonmember Indians, the tribal interest in such jurisdiction outweighs any competing state interest. The Supreme Court has held that states have no criminal jurisdiction over Indians unless it is expressly granted by statute. ${ }^{202}$ The reasoning behind this denial of state jurisdiction is that the Indian territories are

197. Oliphant v. Suquamish Indian Tribe, 435 U.S. 191 (1978).

198. Greywater v. Joshua, 846 F.2d 486, 493 (8th Cir. 1988). Statistics are available showing the relative percentages of nonmember Indians and non-Indians residing on the reservations. See supra note 164 .

199. See supra notes 101, 138-46 and accompanying text; see also Clinton, Isolated in Their Own Country: A Defense of Federal Protection of Indian Autonomy and Self-Government, 33 STAN. L. REV. 979, 1009-10 (1981) (explaining that federal law draws a line between Indians and non-Indians in granting Indians a lesser burden of proof in land cases, in giving them employinent preferences in hiring by the Bureau of Indian Affairs, and in giving them greater fishing and water rights).

200. See supra notes $150-54$ and accompanying text.

201. See supra note 70 (discussing enactment of the Major Crimes Act).

202. Draper v. United States, 164 U.S. 240 (1896); United States v. McBratney, 104 U.S. 621, 624 (1881) (dictum). Of course, when Public Law 280 applies, the state will have at least concurrent jurisdiction. See supra notes 73-82 and accompanying text. Only if nonmembers were awarded the status of non-Indians wonld a state not governed by Public Law 280 or similar legislation have jurisdiction over them. However, there is little reason to divest an Indian of his ethnological heritage 
sovereign bodies on equal footing with the states and possessing an equivalent right to self-governance. ${ }^{203} \mathrm{~A}$ state certainly has no more interest in a crime committed on an Indian reservation than the tribe itself would have, and argnably the state has less of an interest. Rather, it is essential to a tribe's efficient and effective self-governance that it retain a large portion of the power to punish those who have violated its laws.

The examination in section I of the modern concept of enrollment in a tribe as a "inember" illustrates how depriving tribal courts of jurisdiction on the basis of tribal membership can be inappropriate and arbitrary. Modern tribes are not necessarily coinposed of Indians whose descendants shared a common culture and ethnic background. As a result of tribal conquests and intermarriages, for example, ineinbers of one tribe often became members of another. ${ }^{204}$ And throughout American history, the federal government has forced scattered, unrelated Indian cominunities into tribes in order to facilitate negotiations between the government and the tribes. ${ }^{205}$ Moreover, recent government prograins have stimulated the additional novement of Indians among tribes. ${ }^{206}$ As a result of these practices and programs, the modern tribe often has becoine a "melting pot" of Indians.

Current tribal provisions for membership nay prevent nonmenber Indians who have significant contacts with a reservation and are generally considered integral parts of reservation life by tribal members froin becoming tribal inembers. As a result, an Indian may lose his status as a meinber of one tribe and still not qualify for enrollment in another. ${ }^{207}$ Thus, a denial of criminal jurisdiction over nonmember Indians who actively participate in the benefits of reservation life is inappropriate since it creates a class of persons who are without a jurisdictional hone. ${ }^{208}$

Nonmember status deprives an Indian of his right to vote or hold tribal office. ${ }^{209}$ At first glance, it seems fair that one who cannot actively

by classifying him as a non-Indian when there is no advantage to trying him in a state court rather than in a tribal court.

203. See United States v. Wheeler, 435 U.S. 313, 323 (1978) ("[T] trial offenders has never been given up ....").

204. See supra note 29 and accompanying text.

205. See supra notes $30-32$ and accompanying text.

206. See supra notes $49-55$ and accompanying text.

207. See supra notes 33-47 and accompanying text.

208. A counter argument to this analysis can be made. Because a tribe is responsible for estabhishing constitutional provisions for membership, the tribe is not in a position to complain that it is deprived of jurisdiction when the accused is not a tribe nember. There is some merit to this contrary position, but it seems unreasonable to expect tribes to be able to amend their constitutional enrollment provisions to provide membership to all Indians who have significant contact with the reservation over time as the kind of contacts may vary widely, nerely to ensure jurisidiction over these Indians.

209. Greywater v. Joshua, 846 F.2d 486, 493 (8th Cir. 1988). 
participate in a tribal government should not be subject to its criminal jurisdiction. ${ }^{210}$ However, as pointed out above, participation in government is not a necessary criteria for asserting jurisdiction over a defendant in any foruin-whether state, federal, or tribal court. ${ }^{211}$

With no empliasis on the potential for political participation, the Supreine Court lias recognized tribal sovereignty to the greatest extent possible, unless it lias been explicitly witlidrawn by treaty or conflicts with an overriding federal interest. ${ }^{212}$ In explaining its loolding in United States v. Mazurie that a tribal council liad autliority to regulate the sale of alcoliolic beverages by non-Indians on the reservation, the Court stated: "The fact that the Mazuries could not become members of the tribe, and therefore could not participate in the tribal government, does not alter our conclusion." 213 Similarly, in Oliphant, the Court's finding thrat a tribe's exercise of criminal jurisdiction over non-Indians was inconsistent with its dependent status was premised upon the overriding interest of the federal government to protect its citizens' individual freedoms and not on the fact tlat these non-Indians did not participate in tribal government. ${ }^{214}$

\section{CONCLUSION}

Whether Indian tribes have inherent sovereignty to exercise criminal jurisdiction over nonmenber Indians who allegedly have committed crimes on their reservations presents a perplexing issue. Analyzing this issue in light of the Supreme Court's three part test for divested sovereignty set forth in Oliphant is not an easy task. The listorical evidence, as encoinpassed in treaties and legislation, is ambiguous and provides little guidance, except for the conclusion that Congress has not yet specifically addressed the jurisdictional status of noninember Indians.

Moreover, tlie final prong of the Oliphant test-whetlier a particular aspect of sovereignty is inconsistent with the tribes' status as dependent nations-is troublesoine to apply. Although the language of the test itself promises to provide a useful strategy to answer this jurisdictional question, the Court's brief discussion of whiat constitutes "inconsistency with the tribes' dependent status" unfortunately does not offer mucl guidance. ${ }^{215}$

210. See id.

211. See supra notes $194-96$ and accompanying text.

212. United States v. Wheeler, 435 U.S. 313, 322 (1978); Oliphant v. Suquamish Indian Tribe, 435 U.S. 191, 208 (1978); see supra notes 147-53 and accompanying text.

213. 419 U.S. 544,557 (1975).

214. Oliphant, 435 U.S. at 210-12.

215. See supra text accomipanying notes $95-100$. 
When confronted with only ambiguous authority on the question whether tribal courts may exercise criminal jurisdiction over nonmember Indians, the Eighth Circuit in Greywater and the Ninth Circuit in Duro reached opposite conclusions. But both courts madequately applied the Oliphant test. The Ninth Circuit, finding that the Court's apphication of Oliphant to non-Indians was not dispositive of the question before it, chose to dismiss the Oliphant analysis altogether. Although recognizing the third prong of the Oliphant analysis as the key to answering the jurisdictional question, the Eighth Circuit, in an equally disappointing opinion, relied in its analysis on inconclusive and imprecise language in Supreme Court cases decided subsequent to Oliphant.

After a more thorough application of the third prong requirement of Oliphant, this Note concludes that tribal courts sliould liave criminal jurisdiction over nonmembers. The current federal policy of self-determination, which advocates giving the tribes as much authority over their territories as possible, and the diminishing importance of tribal meinbership relative to the significance of contacts to a tribe's reservation, strongly supports acknowledging a tribe's criminal jurisdiction over noninembers. 
- 